\title{
Performance Management and Performance Appraisal: Czech Self-Governments
}

\author{
Dagmar Špalková, David Špaček, Juraj Nemec
}

\begin{abstract}
Managing and measuring performance became an important part of administrative reforms motivated by the New Public Management ideology. However, a badly implemented system designed for measuring and managing performance may distort the behaviours of actors. The goal of this paper is to outline the preliminary picture of the current situation of performance management generally and particularly of performance appraisal at the level of the Czech local and regional self-governments. The presented data, despite the fact that our field research covers only a non-representative samples of the "best" self-government bodies, show first that performance and quality management is not a neglected area in the Czech Republic. Its practice is rather decentralized, and the central government focuses on methodical support and coordination rather than on being strict and requiring certain tools to be implemented. The core problems revealed by the interviews are that the implementation of new instruments is usually based on a trial-and-error approach in its beginnings and that the implementation is award- and project-driven. Our preliminary data clearly indicate that the performance-appraisal situation is even more problematic - they indicate that performance-appraisal systems are introduced in only a limited number of self-government authorities. The set of criteria used in the evaluation is problematic, and the objectives of the performance appraisal are unclear for managers. As a general rule, a performance-appraisal system is not directly linked with implemented performance management and especially not with a payment system.
\end{abstract}

\section{Key words:}

performance measurement, performance management, performance appraisal, Czech Republic, local and regional government 


\section{Introduction}

Managing and measuring performance became an important part of administrative reforms motivated by the New Public Management (NPM) ideology. The idea that organizations should measure and actively manage their performance is also a core element of recent public-sector reforms in many countries, because proper performance management has a significant potential to promote the most important principles of modern governance, especially transparency, accountability, and efficiency.

However, managing and especially measuring performance for appraisal is not a simple task. A badly implemented system may distort the behaviours of actors. The goal of this paper is to outline the preliminary picture of the current situation of performance management generally and particularly of performance appraisal at the level of the Czech local and regional self-governments.

The first part of the paper briefly introduces the main aspects and problems of performance management. We then very briefly introduce the Czech local government system. The paper has two core analytical parts. The first analyses the general situation of performance management in the Czech public sector, the second presents results of our research focused on the local government level, providing more details about current the performance-management implementation status. On the non-representative sample of the "best" local government bodies (those awarded by the national prize for their public-management innovations multiple times) we tried to obtain information about the following questions:

- What instruments are used in performance and quality management, for how long, and what is their setup?

- What effects were anticipated before their implementation?

- What effects were actually achieved and why?

- What are the factors supporting implementation, and what are the challenges faced?

The second core part focuses on the situation of the performance appraisal on the level of Czech self-governments. A similar non-representative sample of the "best" bodies is used, and the following research questions were used:

- What is the link between general strategic documents and HRM strategies?

- What criteria are used in employee evaluations, and how is the performance appraisal handled? What is the link between quality management and performance appraisal?

- What procedures are used in performance appraisal, and who is evaluated?

- What are the anticipated and real effects of implemented performance-appraisal systems? 
We are aware that our sample is not representative. Our ambition is not to provide the final picture of the situation. However, approaches and implementation problems of the "best" actors clearly indicate where the Czech public performance management stands today.

\section{Performance management and its complexity in the public sector}

The concept of performance management was persuasively planted in the post-industrial world in the late 1980s and blossomed in the 1990s (Blalock 1999). However, Van Dooren et al. (2010) point out that performance has accumulated multiple and often ambiguous meanings.

For the purposes of this article, we accept that performance management is a systematic process of improving an organization's performance by developing the performance of individual employees or work teams (Armstrong 2009). Performance management may serve as the basis for developing knowledge and worker skills (development purposes) or as a source of information for everyday decisionmaking (administrative purposes). Performance management is based on set objectives and the evaluation of their achievement over a specified period of time. The outcomes of such evaluation may bring about new requirements for employee development and have an impact on changes in remuneration (Noe et al. 2009).

The literature shows that performance management has been implemented by governments using different methods and for different purposes. According to Halligan (2011), performance represents one of the two big issues (together with markets) in public management of the last 15 years; as an international movement, performance management has evolved and incorporated increasingly sophisticated measures. Yet finely tuned and highly effective systems remain elusive.

One of the reasons for this situation is the fact that any performance-management system has to cope with several problems as described in the available academic literature. Problems immediately arise in the first step of performance-management activities, when measurability is usually discussed as a crucial factor in determining the quality of performance data and performance measurement. This dimension of performance research is expected to answer questions such as "What should be measured, and how should it be measured?", "How should the criteria be made operational?", "Does performance measurement measure what it intends to measure?" Another critical issues may emerge when collecting data - performance measurement as the collection of deliberate activities of quantifying performance, which includes defining a measuring object, formulating indicators, collecting data, analyzing data and reporting (Van Dooren et al. 2010). Performance measurement in the public sector is a complex and challenging issue, because in many cases social and non-financial costs and benefits are expected to be measured. It is a complex 
exercise, because it usually combines objective and subjective measures, and the measures often draw together data from a number of sources (Andrews et al. 2006).

Except for problems connected with the issue of how to measure performance, even more important is the proper use of such information to improve the performance. Moynihan and Pandey (2010) argue that governments have devoted extraordinary effort to creating performance data, wagering that it will be used to improve governance, but much remains unknown about the factors associated with the use of that information. Van Dooren et al. (2010) describe various distortions connected with the use of performance information and output as well as the performance-target paradox. Boyne et al. (2006) addressed the question of which aspects of management influence the performance of public agencies, noting that empirical studies of the impact of management on the real performance of public organizations are scarce.

Performance measurement should secure both the accomplishment of the right objectives and the utilization of the right ways leading to their achievement (Pilařová 2008). There are some flaws to this type of evaluation. Performance evaluation often focuses on outcomes, but it is very difficult to identify measurable outcomes for some job positions or specific organizations, and measurable outcomes do not necessarily make up an organization's performance or an employee's complete job content. Organizations and employees often concentrate only on those criteria on the basis of which they are evaluated, while neglecting the others (Kellough 2012). Outcomes achieved by an individual employee do not necessarily depend only on that employee. When organizations focus only on evaluating the performance of their employees, they may fail to meet objectives that are difficult to measure, e.g. customer assistance (Daley 2005). The subject of an evaluation is often an employee's work and social behaviour at an organization; in this case, the evaluation is often based on the conviction that desirable behaviours lead to efficient performances. In connection with this, "behaviour-based rating scales" based on required employee behaviour have been developed (Kellough 2012).

The text above indicates that proper and effective performance management is rather challenging even for developed countries. Our research is focused on the situation in the Czech Republic, representing a transition country from the region of Central and Eastern Europe (CEE). This region is perceived as rather notable for immature democracies and a weak awareness of political and administrative accountability (e.g. Bouckaert et al. 2008; Meyer-Sahling and Veen 2012; Verheijen 2012, Veselý 2013).

The adverse conditions that make for increased risk connected with the implementation of NPM tools and mechanisms in transitional countries particularly include (Nemec and Vries 2015):

a) External factors, such as the level of competitiveness, socio-economic development, the requirements of the rule-of-law principle, the existence of a system of 
checks and balances within the public administration, the tradition of publicadministration accountability in general, the level of (perceived) corruption in the public sector and the use of a merit-or-spoils system in recruiting public servants.

b) Internal (micro-/organizational) factors that determine a level of readiness and the capacities of public administration for the implementation of NPM reforms and instruments, like the control of corruption, the professionalism of the public administration, the general functioning of government and the impartiality of the public service. It can be asked whether it is possible and sensible to sign contracts in countries where the rule of law hardly applies, and whether any governance mechanisms can be expected to work if its apparatus is highly corrupted, and whether improvements can be expected because of performance measurement and management if there is no professional administration.

\section{The Czech self-government system}

Every part of the territory of the Czech Republic is a part of a municipality. As of 1 January 2013, there were 6253 municipalities in the Czech Republic, which are divided into different types: 5437 common municipalities, 214 market towns, 577 cities, 23 statutory cities ${ }^{1}$ and the Capital City of Prague. There are 14 self-governing regions in the Czech Republic (including Prague).

Territorial fragmentation is a real problem. The number of municipalities is extremely high and has increased continuously since 1989. Most are very small: almost three-quarters of the municipalities have populations of fewer than 1000 inhabitants. The regional authorities are not large enough to fulfil the criteria for NUTS II and have been classified as NUTS III.

The status of local self-government is very close to the principles of the European Charter of Local Self-Government. Within the legal limits, municipal selfgovernments have their own budgets and assets and may issue ordinances that bind all individual or corporate bodies within their jurisdiction. Only parliamentary acts can supersede or invalidate these ordinances. Local authorities have their own and delegated powers, although municipalities in the Czech Republic are categorized, and only those in the higher categories can administer delegated responsibilities. Any modification of the powers of local authorities must be decided by parliament. Barring statutory exceptions, local authorities are independent of state supervision. Local key bodies are elected directly by the inhabitants. Mayors (lord-mayors) elected by the municipal assembly head the municipal offices. Local authorities may

1 Whereas the designation of market towns and cities only has a formal character, without any other legal consequences, statutory cities may have their territory subdivided into smaller selfgoverning units: city districts or city boroughs. 
freely associate with other bodies and form regional or other interest-group organizations.

\section{Performance management in Czech self-government}

Performance-management initiatives in the Czech public sector are usually realized "in bulk", together with quality-management initiatives. The authors are well aware that these two terms are far from identical, but the Czech practice does not distinguish between them, and if we focus exclusively on performance management we would miss a lot of relevant data. Therefore we focus our research on both aspects of public management (quality-management and performance-management approaches) in order to obtain a more complex picture.

Performance management and quality management have been perceived as important by every public-administration reform policy since the late 1990s. A national policy on quality support in the Czech Republic was approved by the government in 2000, stressing the EU recommendations concerning the European quality charter, the role of education, benchmarking and learning from good practices, the EFQM excellence model and the ISO 9000 series. Performance and quality management in public administration was highlighted in the period of reform and modernization at the central administration level, which started in March 2004. It was also incorporated into the broad strategy "Efficient Public Administration and Friendly Public Services - Strategy on Realization of Smart Administration in the Period 2007-2015". This 2007 "Smart Administration" strategy required implementing performance- and quality-management systems in public administration, sociological surveying of citizen satisfaction with public-administration operation and continual monitoring of the quality and performance of public administration to serve the achievement of its aims. In 2008, the National Quality Policy was updated with the document "Strategy of National Quality Policy in the Czech Republic for 2008-2013”.

Central governments have avoided being highly directive and top-down in their approach to performance and quality management in Czech public administration. No instrument is obligatory for public authorities, and all activities in the area are voluntary; however, the CAF and benchmarking have been methodically elaborated and promoted by the Ministry of the Interior. Official guideline information was published on various official quality-management websites - particularly on the web pages of the Ministry of the Interior, the National Quality Policy and the Czech Association for Quality.

Since the implementation of performance and quality management in Czech public administration is generally voluntary, with no specific instruments required, it is not possible to provide fully comprehensive information about the current situation. Table 1 indicates the list of performance- and quality-management systems 
awarded by national quality and innovation prizes by the Ministry of the Interior since 2005. It clearly shows that self-governments (municipalities and regions), rather than central authorities, have been active in performance- and quality-management implementation.

Table 1

Performance- and quality-management systems receiving quality awards (2005-2014)

\begin{tabular}{|c|c|c|c|c|c|}
\hline Instrument & $\begin{array}{l}\text { Authorities } \\
\text { awarded }\end{array}$ & $\begin{array}{l}\text { Municipalities } \\
\text { (Municipal } \\
\text { office of) }\end{array}$ & $\begin{array}{l}\text { Regions } \\
\text { (Regional } \\
\text { office of) }\end{array}$ & $\begin{array}{c}\text { Central } \\
\text { authorities }\end{array}$ & Other \\
\hline CAF & 50 & 39 & 9 & 2 & \\
\hline $\begin{array}{l}\text { Local Agenda } 21 \\
\text { and community } \\
\text { planning of social } \\
\text { services }\end{array}$ & 41 & 38 & 2 & & 1 \\
\hline Benchmarking & 23 & 23 & & & \\
\hline ISO 9001 & 21 & 18 & 1 & & 2 \\
\hline ISO 27001 & 5 & 3 & 2 & & \\
\hline EFQM & 4 & 1 & 0 & 1 & 2 \\
\hline EMAS & 4 & 2 & 1 & 1 & \\
\hline $\mathrm{BSC}$ & 3 & 2 & 1 & & \\
\hline ISO 14001 & 2 & 2 & & & \\
\hline Process Analysis & 2 & & 2 & & \\
\hline Citizen Charter & 2 & 1 & & & 1 \\
\hline
\end{tabular}

Source: Authors

Regions and municipalities started to implement performance- and qualitymanagement systems in the late 1990s, using instruments that were used in the private sector (e.g. EFQM, ISO norms, balanced scorecards and benchmarking) as well as instruments that were designed for the public sector (e.g. EIPA's CAF, Local Agenda 21 and community planning instruments that attempt to include citizens in public decision-making processes and deliberations). Such instruments are implemented within a whole organization or only within some executive organizational units; e.g. ISO norms can be certified only in some department(s) of municipal or regional offices.

As pointed out by Zikmunda and Špaček in 2010, when 12 out of 14 regions implemented some quality-management system, a relatively high number of regional-office employees (46.5\% of 225 survey participants) did not know that a quality-management system had been implemented. Previous research indicated that although quality-management systems like CAF and ISO norms may have been 
implemented for several years, employees of regional offices usually do not think that client/citizen satisfaction or employee satisfaction is measured systematically. Employees of regional offices also did not think that quality management was effectively linked to human-resource management. This went hand-in-hand with their opinion that political leaders did not actively support the implementation and development of quality management. Their average opinion was that using qualitymanagement tools did not increase efficiency and client satisfaction or, in general, lead to the anticipated improvements (Špaček 2009; Zikmunda and Špaček 2010).

Table 1 and other sources indicate that the most frequently used performancemanagement measurement tool is the CAF. Revised versions of the CAF were launched in 2002 and 2006. The Czech usage of the instrument shows that the CAF represents a tool providing the first measurement of citizen/client and employee satisfaction in Czech public administration and offering other improvements in public management, such as more strategic orientation and more systematic approaches to managerial practices.

To extend the existing knowledge about performance and quality management in Czech public administration, the authors conducted an empirical survey based on semi-structured interviews to find answers to our research questions. The interviews were held in spring 2014 with representatives of executive bodies of seven self-governments (five municipal offices and two regional offices) that had received awards for quality and innovations from the Czech Ministry of the Interior. This selection was intentional - we assume that the "best" organizations should also have the best performance-appraisal system. The central authorities were not included in the research. All the included municipal offices were municipalities with extended responsibilities. All the respondents were directly involved in projects implementing quality-management systems (as managers and coordinators, rather than mere project team members). The majority of the respondents had long-term experience in positions in Czech public administration. In two cases, two employees participated in a single interview.

\section{Main findings from our field research}

\section{A: Performance-and quality-management instruments used}

When asked about the instruments used, respondents often spoke about the systems for which they received national quality awards. Most of the surveyed public authorities that work with the CAF started to use this instrument in 2004 or 2005 when a support project of the Ministry of the Interior was launched, particularly funding education and training. This is also true for benchmarking, which was adopted due to the Benchmarking Initiative 2005. ISO norms started to be used later (in 2006). The implementation of process-management instruments and EFQM started only recently within the group of surveyed authorities (mainly in 2012). Corporate Social Responsibility is being implemented in one municipal and one 
regional office. Two respondents from municipal offices spoke about their municipalities' participation in the Local Agenda 21 network.

Findings on how the quality initiatives are practised, coordinated and supported by specific internal documents are summarized in Table 2 .

Table 2

Instruments set up within surveyed public authorities

\begin{tabular}{|c|c|c|}
\hline $\begin{array}{c}\text { Instru- } \\
\text { ment }\end{array}$ & Internal guidelines & Practical aspects \\
\hline CAF & $\begin{array}{l}\text { - no special documents, only } \\
\text { national methodology is used }\end{array}$ & $\begin{array}{l}\text { - } \text { mainly since } 2004 \text { or } 2005 \\
\text { CAF team has about ten members on } \\
\text { average } \\
\text { - self-assessment can be organized } \\
\text { annually, almost annually, or every two } \\
\text { years } \\
\text { - CAF can be focused only on the main } \\
\text { executive body of self-government and } \\
\text { its activities } \\
\text { - CAF can be used in a simplified way } \\
\text { for self-assessment of individual } \\
\text { departments of the executive body }\end{array}$ \\
\hline ISO norms & $\begin{array}{l}\text { - strategic documents like } \\
\text { quality policy } \\
\text { - quality guidelines } \\
\text { - work rules (including } \\
\text { information management) }\end{array}$ & $\begin{array}{l}\text { - started in } 2006 \text { or } 2007 \\
\text { - usually only one or a few departments } \\
\text { are certified } \\
\text { - certification process brought many new } \\
\text { internal documents, education, and } \\
\text { training } \\
\text { - annual audits, recertification after three } \\
\text { years } \\
\text { - "only formal" (MO6) }\end{array}$ \\
\hline $\begin{array}{l}\text { Bench- } \\
\text { marking }\end{array}$ & - no special internal documents & $\begin{array}{l}\text { - heads of some departments participate } \\
\text { in work groups of BI } 2005 \text { which usually } \\
\text { meet once a year } \\
\text { - annual data collection } \\
\text { - evaluation two or three times a year }\end{array}$ \\
\hline EFQM & - no special internal documents & - started only recently (2012) \\
\hline $\begin{array}{l}\text { Process } \\
\text { manage- } \\
\text { ment }\end{array}$ & $\begin{array}{l}\text { - guide for process management } \\
\text { (RO1) } \\
\text { - guide for new software (RO1, } \\
\text { MO3) } \\
\text { - no special internal documents } \\
\text { on process management, but } \\
\text { we have a document called } \\
\text { "quality management system } \\
\text { of municipal office" (MO3) }\end{array}$ & $\begin{array}{l}\text { - started only recently (2012) } \\
\text { - process maps go deeper only in five } \\
\text { typified processes (RO1) } \\
\text { in } 2012 \text {, the model was adjusted; in } \\
2013 \text {, training and pilot started, we will } \\
\text { learn how to work with outputs (MO3) }\end{array}$ \\
\hline
\end{tabular}

Source: Authors

The use of instruments is usually coordinated by chief officers or officials (quality managers or internal auditors and their units) who are directly subordinate to them and represent more autonomous units within the organizational structures of the public authorities. If there is no quality-manager position, an internal auditor 
is usually responsible for similar tasks. Only rarely are the coordination tasks assigned to different positions. Only in two municipalities were representatives of the main self-governmental body - the council - directly involved in the project team. In one case, the mayor was a member of the CAF team because of the mayor's active approach to the quality management of the authority and previous experience in executive bodies of the municipality. In the other case, a council member was involved.

Some authorities prefer annual self-evaluation based on the CAF; others organize it every two years as they perceive the annual self-evaluation as "redundant" or even "pointless", because "in two years, more changes in the legislation or in the needs of self-government occur." Three authorities had direct experiences with ISO norms. The measurement of employee satisfaction is usually organized annually (with participation from $15 \%$ to over $80 \%$ ). The measurement of client/citizen satisfaction may follow the CAF cycle (annual/biannual self-evaluation) and is therefore usually not organized throughout the year; data are collected only during certain periods linked to the completion of the CAF self-evaluation reports. Sometimes overly simple questionnaires are used that do not generate sufficient input for managerial decision-making.

When asked about the interconnection of the implemented instruments, respondents were relatively slow to reply. Usually they referred to the role of the $\mathrm{CAF}$ or of client/employee satisfaction measurement in initiating the interconnection and further integration of individual instruments and controlling/evaluation mechanisms.

Similarly to the question on the interconnection between instruments, interconnection between performance management, appraisal and remuneration of employees was a more difficult question for respondents. Interviews indicated that there was a rather weak link between quality management and employee appraisal. Some respondents explicitly stated that there was no link between quality management and employee appraisal. The link between quality management and remuneration was even weaker. Six out of eight authorities emphasized that the link was not formalized, but in practice it exists thanks to salary components which are dependent on performance, such as bonuses for above-standard work.

\section{B: Anticipated and real effects}

Benchmarking was anticipated as an instrument for monitoring productivity, which brought "a better structure of employees", "better substitutability of employees", and an initiator of new instruments like "a system for making appointments". Among its effects, involvement in the BI 2005 network and sharing of good and bad practices were highlighted. Savings were mentioned rather infrequently and were linked to energy costs by one respondent; another respondent spoke about potential central purchases. 
When asked about the anticipated effects of the CAF, two respondents stated that "at that time, nothing special was anticipated", mainly because those who were responsible for following the implementation were unfamiliar with the instrument. A respondent from one regional office stated that, "In the beginning, we had departments with negative attitudes to the instrument. They even thought that it was useless ... but when we carried out the self-evaluation, they started to realize that quality management may make sense." Public servants of three authorities stated that before the CAF implementation it was anticipated that it would serve as an instrument for continual identification of strengths and weaknesses. In two authorities, the CAF was expected to improve their internal and external reputation. One authority anticipated that it would improve their HRM, another that it would increase their readiness for European projects.

When asked about real effects, respondents mostly perceived the CAF as the main initiator of changes. Most of the respondents stated that the CAF had brought better competences: improved targeting ("orientation toward improvements, vision, and missions"), processes ("better internal communication", "order in documents", "regular meetings of management" and "electronization") and project preparation ("we are better at preparing projects"). Some pointed out new knowledge ("employees were trained in quality management minimums"), documents (such as HRM minimums, work rules, descriptions of processes) and new rules (e.g. for accepting proposals for innovations). One respondent emphasized increased employee motivation; another noted positive changes in organizational culture. Two respondents mentioned a client-centred approach and continual surveying of client and employee satisfaction. The CAF was also perceived as the integrator of other methods and an instrument for evaluating strategies.

The interviews indicate that the implementation of ISO norms was awarddriven. Among the real effects, particularly the new, larger volume of documentation was noted by its users. The introduction to process management, clarification of processes and establishment of measurement indicators were also mentioned. One regional office started implementing EFQM because it was perceived as a higher-level instrument that could bring more from private-sector experiences and also better feedback from the external evaluators. One respondent stated that "in some evaluations we received from the external evaluator, it was funny how little effort was enough to have the trend labelled as positive", when referring to increased costs for training without a subsequent evaluation of the quality of the training; the respondent later added that the CAF methodology is being continually improved through its updates.

\section{C: Factors supporting implementation and challenges faced}

Among the supportive factors, the willingness of political leaders and the motivation/enthusiasm of the project team (CAF team) were emphasized. The CAF's "flatness" - its combination of soft and hard criteria - was also mentioned. The ac- 
cessibility of ISO norms to employees was perceived as supportive. Individually, the respondents stressed the role of the previous mayor or head of the office, contacts with chief officers or activities in their association, and projects with other municipalities.

When public servants spoke about restraints, they (mostly individually) stressed the unwillingness of politicians, unrealistic expectations (e.g. that the process management would be implemented within six months) and unclear assignment from politicians, difficulties with team motivation over time, lack of funding and unhealthy competition (with the CAF, external evaluators can be from authorities competing for awards; the unhealthy competition of some members was also noted with the BI 2005). The weaknesses of the instruments were perceived as restraining. Some perceived the flatness of the CAF as a problem allowing them to have almost everything in self-evaluation reports. On the other hand, ISO norms were perceived as unclear, producing too much documentation. ISO 27001 was perceived as more practical than ISO 9001, because it is more connected to real-life situations. The speed of implementation and the necessity to teach the consultant firm was perceived as a restraining factor by ISO users. The limits of benchmarking were linked particularly to the focus of BI 2005 on state administration and to the unavailability of data in some areas. The lack of funding was often perceived as a significant barrier to further development. This can be summarized by the following opinion of one respondent:

Often the modernization depends on the money coming externally ... and if the money does not come we wait even four or five years until it comes... We prepared a project proposal on the implementation of strategic management and project management for 2006 and 2007, but the call was not announced until 2010. Before that time we did not bother ... we only educated certain people to be prepared for the project, which was otherwise hidden in a drawer.

\section{Performance appraisal at the level of the Czech self-governments}

This part focuses on a specific sub-system of performance management - performance appraisal. The main goal is to evaluate - on the small sample of the "best" organizations - if and how the remuneration of public employees is linked to internally collected performance information and data. As the starting point we provide brief info about the Czech public-sector remuneration rules.

In the Czech Republic, there was no general civil-service legislation before 2015, and legislation on employees of public administration is rather fragmented. The Act on Civil Service was proposed by the government, and a first reading was 
held by Parliament in May 2001, but due to a lack of sufficient consensus the act was not approved at that time; it was approved only recently after strong pressure from the European Union.

The rules of employee remuneration have changed recently. In connection with changes in the Labour Code, Government Decree No. 564/2006 Coll. was adopted, enabling authorities to detach from remuneration according to pensionable length of service and to focus more on employee performance. The range of persons with whom a contractual salary may be agreed has been broadened, which will consequently enable the above-standard remuneration and stabilization of exceptionally competent employees and will increase the competitiveness of authorities as employers on the labour market.

There are no legal regulations in the country providing for a specific procedure that would have to be followed by organizations of public administration and the public sector in evaluating their employees or managing performance in general. Only the Labour Code, generally stating the obligation of managerial employees, provides that "to manage and supervise the work of their subordinate employees and assess their work efficiency (productivity) and work results", refers to performance appraisal. Currently, there is no legal regulation in force in the Czech Republic that would provide for the evaluation of public officials.

When evaluating their employees, public servants can follow methodical recommendations published by the Ministry of Regional Development of the Czech Republic in 2005 ("Evaluation of Employees in Public Administration"). The document contains a summary of the basic theoretical principles for employee evaluations, including a detailed description of individual methods. This methodology does not differ from other texts characterizing human-resource management, and it does not contain any special recommendation for public-administration institutions, either, although a practical supplement to the publication, the "methodical materials", is an indisputable contribution. The materials also contain a discussion on the frequently used evaluation scale, the varied proposed criteria for employee evaluation (provided in the annex), instructions for evaluators as well as the evaluated, and a sample form for employee evaluation. It is clear that the implementation of employee evaluation in public-administration institutions in the Czech Republic still depends mostly on the will or arbitrary behaviour of specific chief officers in the institutions.

To obtain information about the practice of performance appraisal at the selfgovernment level, the authors carried out an empirical survey to determine how the evaluation of public servants is organized and implemented, and what its benefits are in practice. The respondents were selected in the same way as in the previous part about performance management. The surveyed municipal offices (MO) have from 150 to 200 employees (public-administration executives), and the regional offices (RO) have about 650 employees. 


\section{Main findings from our research}

\section{A: Performance-appraisal systems used by surveyed self-governments}

The majority of the authorities that received awards for quality/innovation in public administration worked with a performance-appraisal system. A system was not in place in two (MO3 and $\mathrm{RO} 2$ ) of the seven participating authorities. The management of one of the authorities, a metropolitan authority, does not consider evaluation to be necessary, and they hence carry out only an evaluation of benefits from training activities. At the second authority where no performance appraisal system was in place, a regional authority, there had been discontent with the previous system, which was a formal evaluation by means of a questionnaire; a new methodology was developed there with the assistance of experts, but it had not been put into practice after the elections because it was not supported by political leaders.

\section{Table 3}

Characteristics of the implemented performance-appraisal systems

\begin{tabular}{|c|c|c|c|c|}
\hline & Objectives of evaluation & $\begin{array}{c}\text { Areas of } \\
\text { evaluation }\end{array}$ & $\begin{array}{l}\text { Methods of } \\
\text { evaluation }\end{array}$ & Evaluators \\
\hline M01 & $\begin{array}{l}\text { To improve the attitudes of } \\
\text { employees and increase the } \\
\text { quality of their performance }\end{array}$ & $\begin{array}{l}\text { Inputs - } \\
\text { processes - } \\
\text { outputs }\end{array}$ & $\begin{array}{l}\text { Form - } \\
\text { criteria of } \\
\text { evaluation }\end{array}$ & $\begin{array}{l}\text { Senior managers } \\
\text { - their subordinate } \\
\text { employees }\end{array}$ \\
\hline MO2 & $\begin{array}{l}\text { To provide feedback to } \\
\text { employees about their } \\
\text { performance and behaviour } \\
\text { and to increase efficiency }\end{array}$ & $\begin{array}{l}\text { Inputs - } \\
\text { processes - } \\
\text { outputs }\end{array}$ & $\begin{array}{l}\text { Form - } \\
\text { evaluation } \\
\text { according to } \\
\text { competences }\end{array}$ & $\begin{array}{l}\text { Senior managers } \\
\text { - their subordinate } \\
\text { employees }\end{array}$ \\
\hline M04 & $\begin{array}{l}\text { To obtain an objective } \\
\text { picture about employees } \\
\text { and their performance }\end{array}$ & $\begin{array}{l}\text { Processes - } \\
\text { outputs }\end{array}$ & $\begin{array}{l}\text { Verbal } \\
\text { evaluation - } \\
\text { on the basis } \\
\text { of determined } \\
\text { evaluation } \\
\text { areas }\end{array}$ & $\begin{array}{l}\text { Senior managers } \\
\text { - their subordinate } \\
\text { employees }\end{array}$ \\
\hline MO5 & $\begin{array}{l}\text { To establish a healthy } \\
\text { relationship with employees }\end{array}$ & $\begin{array}{l}\text { Inputs - } \\
\text { processes }\end{array}$ & $\begin{array}{l}\text { Form - } \\
\text { based on the } \\
\text { competence } \\
\text { model }\end{array}$ & $\begin{array}{l}\text { a. Senior managers } \\
\text { - their subordinate } \\
\text { employees, } \\
\text { b. Subordinate } \\
\text { employees - their } \\
\text { senior managers }\end{array}$ \\
\hline R01 & Employee satisfaction & $\begin{array}{l}\text { Inputs - } \\
\text { processes - } \\
\text { outputs }\end{array}$ & $\begin{array}{l}\text { a. Evaluation } \\
\text { of senior } \\
\text { managers: } \\
\text { competence } \\
\text { model } \\
\text { b. Employees: } \\
\text { evaluation } \\
\text { according to } \\
\text { criteria }\end{array}$ & $\begin{array}{l}\text { a. } 360^{\circ} \text { (senior } \\
\text { managers, } \\
\text { subordinates, } \\
\text { colleagues), } \\
\text { b. Senior managers } \\
\text { - their subordinate } \\
\text { employees }\end{array}$ \\
\hline
\end{tabular}


Table 3 above summarizes the general characteristics of the performance-appraisal systems applied at the authorities the representatives of which were the interviewed respondents and the internal documents of which, when provided, were the subject of the analysis.

\section{$B$ : Link between general strategic documents and HRM strategies}

Only two authorities (one municipal office and one regional office) have a personnel strategy developed concurrently that would follow, to a certain extent, from the general strategy. Because these two authorities differ in terms of the number of employees and implemented agenda, the need to draw up a personnel strategy is obviously not related to the size of the authority nor to whether the employees are evaluated at the authority. Interviews with the representatives indicated that the creation and implementation of these documents is instead related to the attitude adopted by the authority's management (i.e. the secretary in the municipal office and the director in the regional office) to the role of strategic management.

\section{C: Criteria used in performance appraisal}

At all of the authorities, employees are evaluated by means of defined criteria, sometimes elaborated in the form of a competency model. At the same time, their work is evaluated from the point of view of the fulfilment of objectives set in a preceding period of time. The interviews show that evaluating the achievement of set objectives is perceived as a supplement to the basic evaluation by means of the criteria. Although the representatives of authorities mentioned it, nobody assigned it any considerable significance.

The criteria of evaluation used by authorities are formulated differently at individual authorities and vary in structure and number. Although individual authorities are divided into various departments (sections, units) and their employees have different job descriptions based on that, all employees are usually evaluated according to the same or very similar criteria. They actually differ only in the terminology defining the given characteristics. Only two authorities distinguish between evaluated employees: at one municipal authority, a superior officer selects those from the range of criteria that are relevant for a given position and job description of the evaluated employee; at the regional authority, service personnel are evaluated according to several criteria selected from a broader scale determined for all employees.

All of the authorities use the following three criteria when evaluating their employees: compliance with regulations, timely performance of tasks and the ability to work under stress. In the majority of the authorities, initiative, flexibility, independence and reliability are also evaluated. Apart from the level of spoken and written language, authorities care about the economic efficiency of their employees. In contrast, the criterion of behaviour towards clients is a part of the evaluation at only two authorities. 
An analysis of the documents that were provided for the purpose of the research showed that only one authority had a verbal description of individual criteria available. In all probability, the other authorities do not consider this necessary although the meaning of individual criteria may be perceived differently by various evaluators. Another, better, approach is when evaluators have a verbal description available for individual degrees of an evaluation scale for each criterion, as with the regional authority. However, this approach is unique in practice. A verbal description of the individual degrees of the evaluation scale is more common.

The interviews also indicate that the systems of performance appraisal implemented in practice are not connected to the implemented systems of performance and quality management.

\section{D: Procedures used in performance appraisal}

The interviews showed that the evaluation process at all of the authorities where they have implemented a performance appraisal system has three phases: self-evaluation of an employee, evaluation of an employee by his or her superior and an evaluation interview. The evaluation of employees by their superiors has become a standard part of performance appraisal at all of the authorities, and it is carried out once a year, or twice a year at one authority. Subordinates evaluate their superiors in only two of the addressed authorities. Colleagues also participate in the evaluation at one of those (the regional authority), thereby creating 360-degree feedback.

Only five of the seven authorities have a methodology for performance appraisal. In some cases, the methodology is a part of the working rules; in other cases, it forms a part of the internal salary regulation; in still other cases, it is a completely separate document. Differences were identified in the work with the evaluation scales that are used in performance appraisal. Evaluators use tenths or hundredths at two authorities. They do so in order to ensure a broader range of possibilities for evaluators and the ability to thus distinguish among the employees being evaluated. The use of weights in the evaluation of senior managers of one regional authority is unique. They divide every competence into two subcategories, each with an assigned weight depending on the work position of the employee evaluated (100\% is divided between these two subcategories).

Usually, a performance-appraisal system is implemented through the whole authority, and all employees are evaluated. Only the employees who are employed as short-term assistants or employees just before retirement are usually excluded from the evaluation.

\section{E: Anticipated and real effects of implemented performance-appraisal systems}

In reply to the question about the objectives of the implemented performance-appraisal system, improved performance was mentioned directly by only one authority representative (RO1). The other authorities implemented performance-appraisal 
systems with the aim of obtaining an objective picture about the performance of their employees. The perception of performance appraisal as an instrument used especially for educational purposes was very common (this may be biased by the structure of the respondents). The interviews indicated that although the authorities implemented a performance-appraisal system, they are not necessarily clear about what the systems should contribute to in practice.

According to the respondents, the resulting forms of the outcomes from evaluations depend on the chief officer, i.e. the evaluator. One HR manager said,

Some chief officers, the typical white-collars, still struggle with it. They tend to skimp on it a bit. But it is in turn the secretary's responsibility to push the chief officers... Of course, some chief officers have a tendency to overdo it so that they will be seen as good managers. But because we send it back to them for review several times, they have learned that they cannot praise everybody to the skies but have to realistically evaluate how a person works.

A representative of another authority, also using marks on a scale for the purposes of the evaluation, pointed out,

It is a weak point ... how to cope with the evaluation. If employees are evaluated with some mark, they think it is not good enough for them. And so the chief officers try to give them a better mark ... it is a matter of courage on the side of the chief officers; if they are demanding and give reasons for worse evaluation results ... or if they want to be kind and give everybody above-average or excellent evaluations. As a result, it is necessary to switch to a new evaluation scale and new performance appraisal system over time.

The HR manager of another authority said, "The existence of unaltered criteria leads to a situation where some employees do not think about their answers any more, and the evaluation then loses its information value. The authority wants to change some criteria because work performed by employees also keeps developing." In addition to the role filled by the dutiful approach of an evaluator to the evaluation, a significant role is also played by the applied evaluation scales and the ability of the evaluator to make use of them.

Most respondents stated that evaluating the officials at many authorities also enabled a more profound discussion between employees and their superiors. Superior officials had to find time for their subordinates as part of the evaluation. A space was created not only for the evaluation of an employee's performance itself but also for a discussion about other aspects that employees consider important ("We also talked about whether their children were naughty"). 
It was proved that performance appraisal is not connected to remuneration in the majority of the authorities, i.e. the link to a salary - a performance component is missing. Only one HR manager stated that performance appraisal was introduced with the aim of interconnecting it with remuneration: "Once a year, when we have a blanket evaluation of the whole authority, salaries may be adjusted in connection with that ... I enter the respective mark in our system and a salary may get adjusted according to it." Another HR manager pointed out that,

The objective was not to connect evaluation to remuneration, not at all. We were considering whether we would take this into account somehow ... but there are not many provisions in the legislation that would enable this ... I must admit we have not yet learned how to do it ... there are not efficiency bonuses (as is the case in business companies) ... this would require other than subjective criteria (it is easier in the industry sector, the number of rejections ... fulfilment of standards), here, in public administration, we are not able to develop proper criteria.

\section{Conclusions}

The presented data, despite the fact that our field research covers only a non-representative samples of the "best" self-government bodies, show first that performance and quality management is not a neglected area in the Czech Republic (see especially Table 1). Its practice is rather decentralized, and the central government focuses on methodical support and coordination rather than on being strict and requiring certain tools to be implemented. Public servants do not agree if this is good: some perceive it as supporting the principle of letting those who know the conditions manage; others would welcome at least a certain level of standardization of performance and quality management. Self-governments are much more active in performance and quality management than government at the central (national) level. The core problems revealed by the interviews are that the implementation of new instruments is usually based on a trial-and-error approach in its beginnings and that the implementation is award- and project-driven. Only the CAF and benchmarking produced real effects according to the public servants surveyed.

Our preliminary data clearly indicate that the performance-appraisal situation is even more problematic. The interviews indicate that performance-appraisal systems are introduced in only a limited number of self-government authorities - in our sample of the "best" authorities; two bodies did not use it. The set of criteria used in the evaluation is problematic, and the objectives of the performance appraisal are unclear for managers. As a general rule, a performance-appraisal system is not directly linked with implemented performance management and especially 
not with a payment system. This is a critical issue, because performance bonuses are not marginal (see Jacko 2015).

To summarize, we may state that some performance-management mechanisms are implemented at the Czech self-government level, but the results from their implementation are not in line with the positive expectations of public managers. Many such systems were developed because of available resources, especially thanks to financing from the public-administration-reform resources (or other donors). Performance appraisal systems are almost non-functional and do not provide a predictable and transparent base for allocating bonuses to employees. Such core weaknesses should be addressed in the next phases of the public-administration reform. Certainly, more coordination and advice is necessary.

\section{References}

Andrews, R., G. A. Boyne and R. M. Walker. 2006. "Subjective and Objective Measures of Organizational Performance: An Empirical Exploration.” In G. A. Boyne, K. J. Meier, L. J. O’Toole Jr. and R. M. Walker (eds.). Public Service Performance: Perspectives on Measurement and Management. Cambridge: Cambridge University Press, 14-34.

Armstrong, M. 2009. Armstrong's Handbook of Performance Management. London: Kogan Page.

Blalock, A. B. 1999. "Evaluation Research and the Performance Management Movement: From Estrangement to Useful Integration?” Evaluation 5(2), 117-149.

Bouckaert, G., J. Nemec, V. Nakrošis, G. Hajnal and K. Tõnisson (eds). 2008. Public Management Reforms in Central and Eastern Europe. Bratislava: NISPAcee.

Boyne, G. A., K. J. Meier, L. J. O’Toole and R. M. Walker. 2006. Public Service Performance. Cambridge: Cambridge University Press.

Daley, Dennis M. 2005. “Designing Effective Performance Appraisal Systems.” In S. E. Condrey (ed.). Handbook of Human Resource Management in Government. $2^{\text {nd }}$ edn. San Francisco: Jossey-Bass, 499-527.

Halligan, J. 2011. "Reform Design and Performance in Australia and New Zealand." In T. Christensen and P. Lægreid (eds). Transcending New Public Management. Farnham: Ashgate, 43-64.

Jacko, T. 2015. "Performance Measurement and Performance-Related Pay in Slovak Local Government.” In J. Nemec and M. S. De Vries (eds). Implementation of New Public Management Tools: Experiences from Transition and Emerging Countries. Brussels: Bryulant, 251-266. 
Kellough, Edward J. 2012. "Managing Human Resources to Improve Organizational Productivity: The Role of Performance Evaluation." In N. M. Riccucci (ed.). Public Personnel Management: Current Concerns, Future Challenges. Glenview: Pearson Education, 173-185.

Meyer-Sahling, J.-H. and T. Veen. 2012. "Governing the Post-Communist State: Government Alternation and Senior Civil Service Politicisation in Central and Eastern Europe." East European Politics 28(1), 4-22.

Ministry of Regional Development of the Czech Republic. 2005. Hodnoceni zaměstnanců ve veřejné správě, metodická doporučení [Evaluation of Employees in Public Administration, methodical recommendations]. Project No. $102 / 2004-52$ of the MRD CR.

Moynihan, D. P. and S. K. Pandey. 2010. "The Big Question for Performance Management: Why Do Managers Use Performance Information?" Journal of Public Administration Research and Theory 20, 849-866.

Nemec, J. and M. S. De Vries (eds). 2015. Implementation of New Public Management Tools: Experiences from Transition and Emerging Countries. Brussels: Bryulant.

Noe, R. A., J. R. Hollenbeck, B. Gerhart and P. M. Wright. 2009. Fundamentals of Human Resource Management. $3^{\text {rd }}$ edn. New York: McGraw-Hill.

Pilařová, I. 2008. Jak efektivně hodnotit zaměstnance a zvyšovat jejich výkonnost. Praha: Grada.

Špaček, D. 2009. “Quality Rhetoric and Citizens' Satisfaction Measurement: Selected Practice of the CAF Instrument in Czech Municipal Public Administration." The International Journal of Knowledge, Culture and Change Management 8(10), 91-104.

Van Dooren, W., G. Bouckaert and J. Halligan. 2010. Performance Management in the Public Sector. Oxon: Routledge.

Verheijen, T. J. G. 2012. "Comprehensive Reform and Public Administration in Post-Communist States." In B. G. Peters and J. Pierre (eds.). The SAGE Handbook of Public Administration. London: SAGE Publications Ltd, 590-601.

Veselý, A. 2013. "Accountability in Central and Eastern Europe: Concept and Reality." International Review of Administrative Sciences 79(2), 310-330.

Zikmunda, M. and D. Špaček. 2010. Očekávané a reálné přinosy implementace ř́zení kvality ve veřejné správě. Brno: Masaryk University. 